\title{
The Review Implementation of the Auction Office Echelon I and Echelon II in Realizing the Government's Apparatus Characterized by Professionals at the Ministry for Administrative Reform and Bureaucratic Apparatus
}

\author{
Irawan; Sri Suwitri; Kismartini; Y. A.Warella \\ Public Administration Doctoral Program, \\ Faculty of Social and Political Science, Diponegoro University \\ Semarang, Indonesia \\ (Office Email: prodidap@gmail.com)
}

\begin{abstract}
Image of bureaucratic Indonesia is still has to be improved, in the culture of State apparatus, it is still encountered corruption, collusion and nepotism so that influence on the service organization quality. The Government apparatus professionalism has to be improved, among others through auctions of office accordance with the Act number 5 in 2014 about Civil State. This minister has been carrying out auction office to fill post of Echelon I and Echelon II expected more professionals, performers, providing services in a fair and neutral. This position is expected auction could be a model for applied ministries, agencies and local governments throughout Indonesia. The expected implementation of auction office follow the entire ministries, agencies and local Governments conducted independent providers and controlled by the State Commission on Civil Apparatus, thus creating a civilian employee, professional performers, providing services in a fair and neutral, as well as adhesive and unifying nation.
\end{abstract}

Keywords-Auctions; Eselon I and eselon II; Professionalism; State Apparatus

\section{INTRODUCTION}

According to Bappenas (2004) in the Research Centre for the study of the autonomous performance region LAN (2012:22) reveals that the image of Indonesia still needs to be increased bureaucracy. The condition of the bureaucracy since the new order still lumpy in the culture of the State apparatus, the culture of corruption, collusion and nepotism to the present still often performed by the State apparatus, as well as the low level of public services provided to society has not shown significant improvement, so the public is reluctant to deal with the bureaucracy. The low professionalism also becomes part of the apparatus in question within the bureaucracy in Indonesia. According to Hayat (2013:25), that the concept of the right man on the right place of civil servant placement is still an obstacle in awarding public service process, (bases on ACT number 5 in 2014 about Civil Apparatus, henceforth abbreviated from PNS to ASN). The main factor is the competence that is owned by an employee does not correspond to its own competence, so that implicates against ministries to society. Akbar (2012:39) this is existence compounded of bureaucratic performance friction from the elite level to street level bureaucracy, coupled with problems relationship overlapping structural and conceptual. Therefore, the repair and quality improvement of civil servant should be enhanced, inter alia through the auction Office, Government through Act No. 5 in 2014 about Civil Apparatus of the State provide realistic about repair against the establishment of human resources in the public service.

\section{TheOretical FramewOrK AND METHOD}

Auction terms of Office are more popular around society in recent years. Especially when the Governor of DKI Jakarta takes auction district head and sub district head. The variety responses emerged, ranging from support to don't understand its meaning. The actual auction Office in question is the promotion of an open position (open promotion) for officials of government bureaucracy. It is starting from open promotion done at Ministry for Administrative Reform and Bureaucratic Apparatus known as KEMENPAN RB to fill the post of head employee agency (Bkn) and Penitentiary Administration (LAN), and officials in the Ministry Echelon I at this Ministry. BKN and LAN is an agency called by this Ministry. The success of that model is made in the human resource management career coaching Apparatus, which is included in acceleration program of the bureaucracy reform. A policy made charge material in Act Civil Apparatus of the State. The system says that the coaching career of civil servant is carried out in a closed state, with an open understanding between government agencies. That is what encourages promotion of the publicly position should be immediately implemented.

Through promotion of openly, this Ministry will get a professional structural officials, have high competence, good 
performers, teamwork, and expectations of the organization. In other words, they will get the best between structural officials. Forward will be much more broadly that is open nationally, officials of the region can get to the Centre, the official Center can reach the area. Auction Office also receive positive support from Indonesian House Representative abbreviated as DPR RI, including the Governor of the national resilience Institute sees it from a different pair of glasses, in the future of the promotion system implementation is open or auction will gradually erode the appellation "son" from the Governor to head level. It will also create a healthy competition in local governance. Currently start in March 2016, entire officer Echelon I and Echelon II (Echelon I totaled 9 officials, and Echelon II totaled 27 officials) who occupied the position in the Ministry for Administrative Reform and Bureaucratic Apparatus is the result of an auction which followed from ministries, agencies and local governments.

\section{RESUlT AND DisCUSSION}

Auction Office for apparatus Echelon I and Echelon II at the Ministry for Administrative Reform and Bureaucratic Apparatus, need to be monitored its implementation carried out by the civil Apparatus Commission's, given this Commission is non structural independent and free from political intervention to create a professional and performing civil servant, providing services in a fair and neutral, as well as adhesive and unifying the nation. Technically operational, while waiting for further policy, namely in the form of government regulations, rules and regulations of the Minister President as a follow-up to Act No. 5 in 2014 about Civil State Apparatus so that the results of the auction office professional apparatus, resulting in changes attitude and behavior so as to improve the public service organization with a variety innovations, among other things, drawing up and implementing public service standards, standard operating procedures and minimum service standards.

\section{CONCLUSION}

The implementation of Act No. 5 in 2014 about Civil State Apparatus is very important, it can create a civil servant professional performers, providing services in a fair and neutral to the society, meaning that they have to be professions and management system bases on the civil servant merit or comparisons between qualifications, competence, and performance required by the position with the qualifications, performance and competence owned by candidates in recruitment, adoption, placement and promotion at the Office that is carried out in an open and competitive, in line with good governance, which in turn create a Government that is efficient and effective.

Auction Office is not only carried out at the Ministry for Administrative and Bureaucratic Apparatus but also it is expected to be implemented in all ministries, agencies and local governments.

\section{REFERENCES}

[1] Akbar, Andi Ali Said (2012), Mengurai Hambatan Relasi Struktural Membangun Kompetensi Birokrasi, Civil Service. Jurnal Kebijakan dan Manajemen PNS 6 (2): 38-46

[2] Hayat (2013), Profesioanalitas dan Proporsionalitas: Pegawai Tidak Tetap Dalam Penilaian Kinerja Pelayanan Publik. Jurnal Kebijakan dan Manajemen PNS 7 (2): 24-39.

[3] ----- (2014), Implikasi Undang-Undang Aparatur Sipil Negara Terhadap Peningkatan Kualitas Sumber Daya Aparatur, Jurnal Transformasi Administrasi, PKP2A IV LAN.

[4] Pusat Kajian Kinerja Otonomi Daerah (2012), Pengukuran Kinerja dan Evaluasi Kinerja Manajemen PNS di Daerah. Jurnal Info Kajian Lembaga Administrasi Negara 6 (1): 22-58

[5] Undang-Undang Nomor 5 Tahun 2014 tentang Aparatur Sipil Negara. 